Suvremena psihologija 20 (2017), 2, 151-163

Izvorni znanstveni rad - UDK 159.942.5

DOI: $10.21465 / 2017-$ SP-202-03

\title{
ULOGA STRATEGIJA EMOCIONALNOG NAPORA U OBJAŠNJENJU IZGARANJA NASTAVNIKA*
}

\author{
Ana Slišković \\ Odjel za psihologiju, Sveučilište u Zadru \\ Obala kralja Petra Krešimira IV. 2, 23000 Zadar \\ aslavic@unizd.hr \\ Irena Burić \\ Odjel za psihologiju, Sveučilište u Zadru \\ Obala kralja Petra Krešimira IV. 2, 23000 Zadar \\ inekic@unizd.hr \\ Lucija Bubić \\ Krešimirova ulica 34, 21211 Vranjic \\ bubiclucija@gmail.com
}

\begin{abstract}
Sažetak
Iako su prediktori i ishodi izgaranja u različitim profesijama, uključujući nastavničku, relativno česta tema istraživanja, uloga strategija emocionalnog napora u objašnjenju sržnih dimenzija izgaranja manje je istraživana, osobito kod hrvatskih nastavnika. Stoga je cilj ovog istraživanja bio ispitati ulogu strategija emocionalnog napora (dubinska strategija, te dvije površinske strategije: prikrivanje osjećaja i glumljenje emocija) u objašnjenju iscrpljenosti i otuđenosti nastavnika. U istraživanju je sudjelovalo ukupno 1955 nastavnika, od čega 581 učitelj razredne nastave, 716 nastavnika predmetne nastave u osnovnoj školi, te 538 srednjoškolskih nastavnika. U uzorku su bile zastupljenije nastavnice (1648 nastavnica i 307 nastavnika), a raspon dobi se kretao od 23 do 68 godina $(M=42,38, S D=10,12)$. Rezultati su pokazali značajan, iako relativno malen, doprinos strategija emocionalnog napora u objašnjenju izgaranja na poslu. Pri tome nastavnici koji češće koriste površinske strategije emocionalnog napora (prikrivanje i glumljenje osjećaja) imaju više razine iscrpljenosti i otuđenosti. Suprotno tome, korištenje dubinske strategije emocionalnog napora vezano je za niže razine izgaranja.
\end{abstract}

Ključne riječi: strategije emocionalnog napora, izgaranje, nastavnici

* Istraživanje je provedeno u sklopu projekta Teacher's emotions and emotion regulation strategies: Personal and contextual antecedents and effects on motivation, well-being and relationship with students koji je financirala Hrvatska zaklada za znanost. 


\section{UVOD}

Rezultati istraživanja koja se bave nastavničkom profesijom potvrđuju da je i danas aktualan petnaestak godina star navod Kyriacoua (2001) o stresu kao intrinzičnom obilježju nastavničke profesije. Nastavnici se, naime, u svom radu susreću s velikim brojem izvora stresa (Montgomery i Rupp, 2005) koji mogu voditi negativnim ishodima po njihovu psihofizičku dobrobit i kvalitetu njihova rada te posljedično na društvo u cjelini (Slišković, 2016). Istraživanja provedena posljednjih desetak godina pokazala su da se hrvatski nastavnici na svim razinama obrazovanja suočavaju s različitim radnim stresorima (Slišković, Burić i Macuka, 2016; Slišković i Maslić Seršić, 2011) te da otprilike 30\% zaposlenih nastavnika izražava želju za napuštanjem posla (Radeka i Sorić, 2006). Doživljaj stresa na poslu, smanjena dobrobit i želja za napuštanjem posla u najvećoj se mjeri povezuju s lošim radnim uvjetima i nepovoljnim profesionalnim statusom u društvu (Kadum, Vidović i Vranković, 2007; Slišković i sur., 2016; Vidić, 2009; Vizek Vidović, 2005). Usprkos nezadovoljstvu s različitim aspektima posla, hrvatski su nastavnici, u prosjeku gledano, zadovoljni svojim poslom, osobito radom s učenicima (Vizek Vidović, 2005), čemu uvelike doprinosi njihova intrinzična motivacija (Rijavec, Pečjak, Jurčec i Gradišek, 2016).

U usporedbi s istraživanjima (ne)zadodovoljstva i profesionalnog stresa kod nastavnika, relativno je manje pažnje, osobito u hrvatskim istraživanjima, posvećeno ulozi emocija, emocionalne regulacije i emocionalnog napora u radu nastavnika. U novije vrijeme prepoznato je da svakodnevni rad nastavnika podrazumijeva emocionalno zahtjevne interakcije s učenicima, roditeljima, kolegama, nadređenima i ostalim dionicima obrazovnog sustava (Sutton i Wheatley, 2003; Burić, Slišković i Macuka, 2017). Naime, nastavnici u svom radu doživljaju različite ugodne i neugodne emocije koje moraju regulirati kako bi mogli ispuniti različite nastavne ciljeve. Zbog toga se nastavnička profesija smatra jednom od emocionalno zahtjevnijih profesija (Chan, 2006), u kojoj je u velikoj mjeri izražen emocionalni napor (Tsang, 2011).

Važna komponenta definicije emocionalnog napora odnosi se na prisutnost očekivanja vezanih za radnu ulogu. Naime, emocionalni napor se javlja kada djelatnici reguliraju svoje emocije i njihovo izražavanje u skladu s normativnim zahtjevima i očekivanjima specifične radne uloge (Brotheridge i Lee, 2003). S obzirom na to da u nastavničkoj profesiji postoje brojna implicitna pravila vezana uz izražavanja emocija (Yin, 2015), jasno je da je emocionalni napor uvelike izražen i u nastavničkoj profesiji. Tsang (2011) navodi kako profesija nastavnika sve više nalikuje na uslužne djelatnosti, što smatra posljedicom brojnih promjena i reformi koje se provode u zadnje vrijeme. Naime, roditelji i djeca se sve više tretiraju kao klijenti i nastavnici moraju slijediti implicitna pravila izražavanja emocija. Primjerice, nije poželjno da nastavnici emocije izražavaju presnažno ili pak preslabo, nije poželjno da izražavaju neugodne emocije kao ni ekstremnu sreću, a, s druge strane, poželjno je da su entuzijastični i da imaju smisao za humor (Tsang, 2011). 
Ako se emocije koje se prirodno javljaju razlikuju od socijalno poželjnih ili očekivanih emocija, pojedinac doživljava emocionalnu disonancu (Ashforth i Humphrey, 1993). Emocionalnu disonancu je moguće riješiti promjenom izražavanja prirodnih emocija (površinska strategija emocionalnog napora, engl. surface acting) ili pokušajem "prizivanja" prikladnih emocija unutar sebe (dubinska strategija emocionalnog napora, engl. deep acting). Obje strategije omogućuju pojedincima da izraze očekivane emocije koje se kod njih ne javljaju spontano (Yin, Lee, Zhang, Jin, 2013), međutim ove se dvije strategije uvelike razlikuju. Površinska strategija emocionalnog rada podrazumijeva prikrivanje doživljenih emocija koje nisu u skladu s zahtjevima radne uloge te izražavanje prikladnih ili očekivanih emocija koje nisu uistinu doživljene (Brotheridge i Lee, 2003). S druge strane, kod dubinske strategije emocionalnog napora pojedinac pokušava uskladiti doživljene i očekivane emocije na način da pokušava uistinu doživjeti emocije koje se od njega očekuju (Brotheridge i Lee, 2003). U novije vrijeme, Lee i Brotheridge (2011) razdvajaju dvije osnovne potkomponente površinske strategije emocionalnog napora: skrivanje doživljenih emocija (koje nisu u skladu s radnim zahtjevima) i glumljenje emocija (izražavanje prikladnih emocija koje nisu doživljene). Konceptualno razdvajanje površinske strategije na dvije komponente od posebne je važnosti s obzirom na obilježja učiteljskog posla. Naime, učitelji često u svom poslu moraju slijediti određena emocionalna pravila učiteljske profesije, tj. prikrivati neugodne osjećaje (npr. anksioznost ili bijes), održavati ugodne (npr. ponos, radost) te općenito izražavati svoje emocije umjerenim intenzitetom (Winograd, 2003; Yin i Lee, 2012). Primjerice, učitelj će povremeno "odglumiti” entuzijazam prema nekom gradivu kako bi pobudio interes učenika za učenje. S druge strane, kako bi održao autoritet u razredu, nastojat će prikriti svoju anksioznost koju osjeća u radu s učenicima problematičnog ponašanja. S obzirom na to da ove dvije komponente površinske strategije mogu pokazivati različite obrasce povezanosti s relevantnim ishodima, $u$ ovom radu odlučeno je ispitivati ih odvojeno.

Važnost istraživanja emocionalnog napora očigledna je iz rezultata istraživanja koja upućuju na negativne ishode emocionalnog napora po psihofizičko zdravlje, izgaranje na poslu i napuštanje posla (Brotheridge, 2006). Međutim, istraživanja u različitim profesijama pokazuju da nisu sve strategije emocionalnog napora jednako prediktivne za negativne ishode (Chau, Dahling, Levy i Diefendorff, 2009; Schmidt i Diestel, 2014). Rezultati istraživanja većinom pokazuju da su površinske strategije emocionalnog napora one koje vode osjećaju neautentičnosti te koje dugoročno gledajući mogu narušiti emocionalnu dobrobit (Brotheridge i Lee, 2003). S druge strane, iako se intuitivno može činiti da je dubinska strategija ona koja traži više napora i više emocionalno iscrpljuje, rezultati istraživanja pokazuju da korištenje dubinske strategije zapravo smanjuje emocionalnu disonancu i izaziva pozitivne reakcije klijenata, što dugoročno vodi pozitivnim učincima na dobrobit (Grandey, 2000, 2003). 
S obzirom na to da se emocionalni napor smatra jednim od proksimalnih prediktora izgaranja na poslu (Brotheridge i Grandey, 2002), u ovom smo se radu fokusirali na ispitivanje uloge emocionalnog napora u objašnjenju izgaranja na poslu kod hrvatskih nastavnika. Pri tome smo koristili dvodimenzionalnu konceptualizaciju izgaranja na poslu koju su postavili Demerouti i suradnici (Bakker, Demerouti i Verbeke, 2004; Demerouti, Bakker, Vardakou i Kantas, 2003; Demerouti i Bekker, 2008) i koja se pokazala u dosadašnjim istraživanjima kao teorijski i psihometrijski prikladnom alternativom trodimenzionalnoj konceptualizaciji izgaranja autorice Maslach (Maslach i Jackson, 1981). Prema navedenim autorima, dvije sržne dimenzije izgaranja su iscrpljenost i otuđenost. Pri tome je iscrpljenost definirana kao posljedica intenzivnog fizičkog, afektivnog i kognitivnog stresa, dok se otuđenost odnosi na vlastitu distanciranost od posla općenito (Demerouti, Mostert i Bakker, 2010).

Dosadašnja istraživanja odnosa emocionalnog napora i izgaranja na poslu nastavnika na uzorcima izvan Hrvatske pokazala su da visoke razine emocionalnog napora mogu voditi profesionalnom izgaranju (Kinman, Wray i Strange, 2011). Međutim, i na uzorcima nastavnika potvrđen je različit obrazac povezanosti različitih strategija emocionalnog napora i dimenzija izgaranja. Tako je dobiveno da su površinske strategije emocionalnog napora one koje emocionalno iscrpljuju nastavnike te s obzirom na njihovu pozitivnu povezanost s dimenzijama izgaranja (Chang, 2009; Çukur, 2009; Ghanizadeh i Royaei, 2015; Näring, Briët, Brouwers, 2006; Noor i Zainuddin, 2011) posljedično vode k iscrpljenosti i otuđenosti. Dubinska strategija emocionalnog napora, iako crpi resurse pojedinca, prema Cheung, Tang i Tang (2011), ima pozitivne posljedice za izvedbu pojedinca te stoga nije značajno povezana s izgaranjem. Philipp i Scühpbach (2010) su u longitudinalnom istraživanju utvrdili da dubinska strategija dugoročno smanjuje iscrpljenost.

S obzirom na navedeno, cilj ovog rada bio je ispitati ulogu strategija emocionalnog napora u objašnjenju izgaranja hrvatskih nastavnika. Preciznije, osnovni istraživački problem bio je ispitati doprinose strategija emocionalnog napora (površinskih strategija: prikrivanje osjećaja i glumljenje emocija, te dubinske strategije) u objašnjenju varijance dviju dimenzija profesionalnog izgaranja nastavnika (iscrpljenosti i otuđenosti), uz kontrolu osnovnih demografskih karakteristika nastavnika (spola i radnog staža). Pri tome je u skladu s rezultatima dosadašnjih istraživanja pretpostavljeno da će češće korištenje površinskih strategija emocionalnog napora zbog nedostatka autentičnosti i kontrole koju pojedinac ima, pridonositi izgaranju na poslu. Suprotno tome, budući da pojedinci koji koriste dubinsku strategiju emocionalnog napora imaju veći osjećaj postignuća i autentičnosti, pretpostavljeno je da pojedinci koji češće koriste dubinsku strategiju emocionalnog napora doživljavaju niže razine izgaranja. 


\section{METODA}

\section{Sudionici}

U istraživanju je sudjelovalo ukupno 1955 nastavnika iz osnovnih i srednjih škola u Republici Hrvatskoj, od čega je bilo 307 nastavnika i 1648 nastavnica. Raspon dobi nastavnika bio je između 23 i 68 godina $(M=42,38, S D=10,12)$. Ukupan uzorak nastavnika sastojao se od tri podskupine zaposlene na različitim obrazovnim razinama; učitelji razredne nastave $(\mathrm{N}=581)$, nastavnici predmetne nastave zaposleni u osnovnoj školi $(\mathrm{N}=716)$ i nastavnici predmetne nastave u srednjoj školi $(\mathrm{N}$ =536). Prosječan radni staž nastavnika iznosio je 15,9 godina $(S D=10,42)$.

\section{Mjerni instrumenti}

U istraživanju su uz osnovne sociodemografske karakteristike zahvaćene mjere emocionalnog napora i izgaranja na poslu.

Emocionalni napor mjeren je revidiranom verzijom Skale emocionalnog napora (engl. Emotional Labour Scale, Brotheridge i Lee, 2003; Lee i Brotheridge, 2011). Skala se sastoji od ukupno devet čestica, od kojih tri čestice mjere dubinsku strategiju emocionalnog napora (npr. "Stvarno nastojim osjetiti emocije koje bih trebao/la iskazivati kao dio svog posla"), tri čestice mjere prikrivanje osjećaja (npr. "Skrivam svoje istinske osjećaje o nekoj situaciji”) i tri čestice mjere glumljenje emocija (npr. "Pokazujem emocije koje ne osjećam"). U svrhu provjere pretpostavljene trofaktorske strukture skale na rezultatima dobivenima u ovom istraživanju provedena je konfirmatorna faktorska analiza u programu Statistica (verzija 13.2). Pri tome je u skladu s teorijskim polazištem pretpostavljena korelacija između dvije površinske strategije emocionalnog napora. Konfirmatorna faktorska analiza rezultirala je sljedećim indeksima slaganja: $\chi^{2}=295,46, d f=26, p<0,01$; GFI $=0,97$ i CFI = 0,96; RMSEA $=0,08(0,069-0,084)$ i SRMR $=0,04$. Na osnovi ovih vrijednosti, može se zaključiti da, prema većini indeksa (GFI, CFI, RMSEA i SRMR), testirani model izvrsno pristaje podacima (Hu i Bentler, 1999), dok to nije slučaj za omjer $\chi^{2}$ i stupnjeva slobode. Ipak s obzirom na vrijednosti svih ostalih indeksa te na činjenicu da su sva zasićenja čestica pretpostavljenim faktorima bila veća od 0,50 (Brown, 2006), odlučeno je ostati pri trofaktorskoj strukturi skale. Ova odluka ima opravdanje i u teorijskoj podlozi skale, a u prilog joj idu i zadovoljavajuće pouzdanosti triju subskala (v. Tablicu 1). Zadatak nastavnika koji su sudjelovali u ovom istraživanju bio je da na skali od 5 stupnjeva (1=nikada; 5=uvijek) označe koliko se često upuštaju u određene interakcije sa svojim učenicima tijekom prosječnog radnog dana. Ukupan rezultat na trima subskalama formira se kao prosjek odgovora sudionika na pripadajućim česticama, pri čemu viši rezultat na određenoj subskali označava češće korištenje određene strategije emocionalnog napora. 
Za mjerenje izgaranja na poslu korišten je Oldenburški upitnik izgaranja (engl. The Oldenburg Burnout Inventory; Demerouti i Bakker, 2008), koji su na hrvatski jezik adaptirale Burić i Slišković (2018). Upitnik se sastoji od ukupno 16 tvrdnji, odnosno od dvije skale koje mjere dvije dimenzije izgaranja; skale iscrpljenosti $\mathrm{i}$ skale otuđenosti, od kojih svaka sadrži po 8 tvrdnji. Skala iscrpljenosti svojim sadržajem odnosi se na osjećaj praznine, preopterećenosti, fizičke iscrpljenosti i snažne potrebe za odmorom (pr. čestice: "Dok radim, često se osjećam emocionalno iscijeđeno"), dok se skala otuđenosti odnosi na negativne i cinične stavove i ponašanja prema svom poslu (pr. čestice: "Sve češće se događa da o svom poslu pričam na negativan način"). Empirijski podaci na uzorku hrvatskih nastavnika (Burić i Slišković, 2018) potvrđuju opravdanost dvofaktorske strukture koju su pretpostavili autori izvorne verzije.

Zadatak sudionika je iskazati svoj stupanj slaganja na ljestvici od 4 stupnja, pri čemu 1 označava neslaganje sa zadanom tvrdnjom ( 1 = uopće se ne slažem), a 4 označava potpuno slaganje $(4=$ potpuno se slažem). Ukupno 8 tvrdnji iz cijelog upitnika boduje se obrnuto. Ukupan rezultat na dvjema skalama odgovara prosjeku svih tvrdnji pripadajućih skala. Viši rezultat na skalama izgaranja označava višu razinu izgaranja na poslu, odnosno višu iscrpljenost i otuđenost. Skale su pokazale zadovoljavajuću unutrašnju konzistenciju (v. Tablicu 1). Rezultati na dvije dimenzije izgaranja međusobno su povezani (v. Tablicu 2), što je teorijski i očekivano.

\section{POSTUPAK}

Podaci prikazani u ovom radu prikupljeni su u drugom valu istraživanja koje je provedeno u proljeće 2016. godine. Upitnici su poslani nastavnicima koji su sudjelovali u prvom istraživačkom valu (3010 nastavnika zaposlenih u 156 osnovnih i srednjih škola u različitim mjestima, gradovima i županijama Republike Hrvatske). Odaziv nastavnika u drugom istraživačkom valu iznosio je oko 65\% (1955 od 3010 nastavnika kojima su poslani upitnici). S obzirom na to da je u prvom istraživačkom valu odaziv bio oko 50\% (3010/6000), može se kazati da je ukupan odaziv u ovom istraživanju u odnosu na ciljanu populaciju nastavnika oko $35 \%$.

Upitnici su primijenjeni u papir-olovka obliku te su distribuirani putem pošte na adresu škole, gdje su u njihovoj daljnjoj distribuciji pomogli stručni suradnici. Svaki sudionik dobio je svoj upitnik u omotnici koja je sadržavala sam upitnik, s uputama i zamolbu u kojoj je objašnjena svrha istraživanja te naglašena anonimnost sudionika.

\section{REZULTATI}

Iz deskriptivnih podataka (Tablica 1) vidljivo je kako sve korištene varijable značajno odstupaju od normalne distribucije (Kolmogorov-Smirnovljev test), ali 
Tablica 1 Prikaz deskriptivnih parametara korištenih mjera $(N=1955)$

\begin{tabular}{lcccccccc}
\hline Mjere & M & Min & Max & Sd & K-S d & $\begin{array}{c}\text { Asimetričnost } \\
\text { (Stand. pogr.) }\end{array}$ & $\begin{array}{c}\text { Spljoštenost } \\
\text { (Stand. pogr.) }\end{array}$ & $\begin{array}{c}\text { Cronbach } \\
\alpha\end{array}$ \\
\hline $\begin{array}{l}\text { Dubinska } \\
\text { strategija }\end{array}$ & 3,42 & 1 & 5 & 0,96 & $0,13^{*}$ & $\begin{array}{c}-0,66 \\
(0,66)\end{array}$ & $\begin{array}{c}0,19 \\
(0,11)\end{array}$ & 0,86 \\
$\begin{array}{l}\text { Prikrivanje } \\
\text { osjećaja }\end{array}$ & 2,40 & 1 & 5 & 0,75 & $0,09 *$ & $\begin{array}{c}0,17 \\
(0,06)\end{array}$ & $\begin{array}{c}0,02 \\
(0,11)\end{array}$ & 0,80 \\
$\begin{array}{l}\text { Glumljenje } \\
\text { emocija }\end{array}$ & 1,95 & 1 & 5 & 0,73 & $0,12^{*}$ & $\begin{array}{c}0,58 \\
(0,66)\end{array}$ & $\begin{array}{c}0,02 \\
(0,11)\end{array}$ & 0,76 \\
$\begin{array}{l}\text { Iscrpljenost } \\
\text { Otuđenost }\end{array}$ & 2,16 & 1 & 4 & 0,48 & $0,10^{*}$ & $\begin{array}{c}0,07 \\
(0,06)\end{array}$ & $\begin{array}{c}0,27 \\
0,11)\end{array}$ & 0,81 \\
& 2,02 & 1 & 4 & 0,47 & $0,07 *$ & $\begin{array}{c}0,14 \\
(0,06)\end{array}$ & 0,80 \\
\hline
\end{tabular}

$* p<0,05$

prema koeficijentima asimetričnosti i spljoštenosti varijable se nalaze u rasponu vrijednosti koje su prihvatljive za korištenje parametrijskih statističkih analiza. Također, vidljivo je kako su prosječni rezultati za površinske strategije emocionalnog napora i mjere izgaranja pomaknuti prema nižim vrijednostima, dok se rezultati za dubinsku strategiju emocionalnog napora kreću prema višim vrijednostima.

Prije prikaza ispitivanja doprinosa strategija emocionalnog napora u objašnjenju izgaranja na poslu, izračunate su bivarijatne povezanosti između svih korištenih mjera emocionalnog napora (dubinska strategija, prikrivanje osjećaja i glumljenje emocija) i izgaranja na poslu (emocionalna iscrpljenost i otuđenost) pomoću Pear-

Tablica 2 Prikaz Pearsonovih koeficijenata korelacije između ispitivanih varijabli $\left(N^{1}=1900\right)$

\begin{tabular}{|c|c|c|c|c|c|c|c|c|}
\hline & 1 & 2 & 3 & 4 & 5 & 6 & 7 & 8 \\
\hline 1 Spol & 1 & 0,02 & $0,08 * *$ & $0,05^{*}$ & $-0,02$ & $-0,06^{* *}$ & $0,08 * *$ & $-0,05^{*}$ \\
\hline 2 Dob & & 1 & $0,90 * *$ & $0,07 * *$ & $0,08 * *$ & $-0,02$ & $0,06^{*}$ & $-0,03$ \\
\hline 3 Radni staž & & & 1 & $0,07 * *$ & $0,07 * *$ & $-0,01$ & $0,07 * *$ & $-0,03$ \\
\hline 4 Dubinska strategija & & & & 1 & 0,00 & 0,03 & $-0,07 * *$ & $-0,18^{* *}$ \\
\hline 5 Prikrivanje osjećaja & & & & & 1 & $0,61 * *$ & $0,27 * *$ & $0,31 * *$ \\
\hline 6 Glumljenje emocija & & & & & & 1 & $0,22 * *$ & $0,28 * *$ \\
\hline 7 Iscrpljenost & & & & & & & 1 & $0,69 * *$ \\
\hline 8 Otuđenost & & & & & & & & 1 \\
\hline
\end{tabular}

${ }^{1} \mathrm{~N}$ je uvjetovan činjenicom da manji dio sudionika nije dao odgovor na dio pitanja o demografskim karakteristikama.

${ }^{*} p<0,05, * * p<0,01$ 
sonovih koeficijenata korelacije. U matrici korelacija (Tablica 2) dodane su i osnovne demografske varijable (spol, dob i radni staž).

Strategije emocionalnog napora značajno su povezane s mjerama izgaranja. Nastavnici koji češće koriste dubinsku strategiju manje su iscrpljeni i manje otuđeni, pri čemu je visina povezanosti niska, osobito kod iscrpljenosti. Nadalje, nastavnici koji češće koriste površinske strategije emocionalnog napora, ujedno pokazuju i više razine iscrpljenosti i otuđenosti. Veličina koeficijenata korelacije između površinskih strategija emocionalnog napora i mjera izgaranja nešto su više u odnosu na dobivene povezanosti za dubinsku strategiju, ali ipak najviše umjerene (od 0,22 do 0,31 ).

Međusobni odnosi između pojedinih strategija emocionalnog napora u skladu su s očekivanjem. Površinske strategije emocionalnog napora značajno su pozitivno povezane, dok nisu povezane s dubinskom strategijom emocionalnog napora. Dvije dimenzije izgaranja su relativno visoko pozitivno povezane, odnosno višu razinu iscrpljenosti prati viša razina otuđenosti, što je također teorijski očekivano.

Konačno, dobivene su značajne, iako niske, korelacije između osnovnih sociodemografskih karakteristika i ostalih korištenih varijabli. Podaci pokazuju da nastavnice više koriste dubinsku strategiju emocionalnog napora te su ujedno više iscrpljene. S druge strane, nastavnici više koriste strategiju glumljenje emocija i više su otuđeni. Stariji nastavnici i nastavnici s više radnog staža više koriste dubinsku strategiju i prikrivanje osjećaja te su više iscrpljeni.

$\mathrm{Da}$ bi se ispitalo doprinose li strategije emocionalnog napora (dubinska strategija, prikrivanje osjećaja i glumljenje emocija) u objašnjenju izgaranja na poslu

Tablica 3 Prikaz rezultata dviju hijerarhijskih regresijskih analiza sa spolom, radnim stažem i strategijama emocionalnog napora kao prediktorima i dimenzijama izgaranja (iscrpljenosti i otuđenosti) kao kriterijima $\left(N^{1}=1929\right)^{2}$

\begin{tabular}{lcc}
\hline & Iscrpljenost & Otuđenost \\
\hline Prediktori & $\beta$ & $\beta$ \\
\hline Spol & $0,09^{* *}$ & $-0,03$ \\
Radni staž & $0,06^{* *}$ & $-0,02$ \\
$R^{2}$ & $0,01^{* *}$ & 0,00 \\
Dubinska strategija & $-0,08^{* *}$ & $-0,18^{* *}$ \\
Prikrivanje osjećaja & $0,20^{* *}$ & $0,22^{* *}$ \\
Glumljenje emocija & $0,11^{* *}$ & $0,16^{* *}$ \\
$\Delta R^{2}$ & $0,08^{* *}$ & $0,14^{* *}$ \\
$R^{2}$ & $0,09^{* *}$ & $0,14^{* *}$ \\
\hline
\end{tabular}

${ }^{1} N$ je uvjetovan činjenicom da manji dio sudionika nije dao odgovor na dio pitanja o demografskim karakteristikama.

${ }^{2}$ Prikazani su rezultati zadnjeg koraka hijerarhijske regresijske analize.

$* * p<0,01$ 
(iscrpljenost i otuđenost), provedene su dvije hijerarhijske regresijske analize (Tablica 3). U prvom su koraku, kao kontrola uvedeni spol i radni staž, a u drugom tri strategije emocionalnog napora.

Rezultati su pokazali značajan, iako nizak (svega 1\%), doprinos spola i radnog staža u objašnjenju iscrpljenosti, ali ne i otuđenosti. Žene i nastavnici duljeg radnog staža doživljavaju više razine iscrpljenosti. Strategije emocionalnog napora značajno doprinose objašnjenju iscrpljenosti i otuđenosti, iako je udio objašnjene varijance dviju mjera izgaranja pomoću strategija emocionalnog napora relativno nizak ( $8 \%$ varijance iscrpljenosti i $14 \%$ varijance otuđenosti). Pri tome su sve tri strategije emocionalnog napora imale značajne doprinose. Nastavnici koji češće koriste površinske strategije emocionalnog napora pokazuju više razine iscrpljenosti i otuđenosti, dok je češće korištenje dubinske strategije nastavnika prediktor njihove manje iscrpljenosti i otuđenosti.

\section{RASPRAVA}

S obzirom na relativno oskudne spoznaje o odnosu emocionalnog napora i dimenzija izgaranja kod hrvatskih nastavnika, osnovni cilj ovog rada bio je testirati ulogu strategija emocionalnog napora u objašnjenju iscrpljenosti i otuđenosti nastavnika.

Dobiveni rezultati u skladu su s hipotezom postavljenom na osnovi dosadašnjih spoznaja o odnosu strategija emocionalnog napora i izgaranja na stranim uzorcima (Chang, 2009; Cheung i sur., 2011; Çukur, 2009; Ghanizadeh i Royaei, 2015; Näring i sur., 2006; Noor i Zainuddin, 2011). Prikrivanje osjećaja pokazalo se relativno najboljim prediktorom iscrpljenosti i otuđenosti. Glumljenje emocija također značajno predviđa iscrpljenost $\mathrm{i}$ otuđenost iako nešto manje nego prikrivanje osjećaja. Dubinska strategija emocionalnog napora, značajan je prediktor za obje komponente izgaranja, odnosno oni nastavnici koji uistinu pokušavaju doživjeti emocije koje su prikladne, osjećaju se manje iscrpljeno i otuđeno. Ukupno gledajući, strategije emocionalnog napora nešto bolje objašnjavaju otuđenost u odnosu na iscrpljenost. Dobiveni rezultati idu u prilog ranijim navodima da površinske strategije, zbog nedostatka autentičnosti i kontrole koju pojedinac ima (Brotheridge i Lee, 2002), zahtijevaju puno više resursa i napora od pojedinca. Dubinska strategija, pak, smanjuje emocionalnu disonancu i izaziva pozitivne reakcije okoline, što na neki način vraća resurse pojedincu (Grandey, 2003) i time čak smanjuje iscrpljenost, odnosno izgaranje (Philipp i Schüpbach, 2010). Ipak, istraživanje je pokazalo na relativno malen udio objašnjenosti varijance izgaranja, što je razumljivo s obzirom da su antecedenti izgaranja višestruki. Naime, antecedenti izgaranja obuhvaćaju: individualne (demografske karakteristike, osobine ličnosti), organizacijske (organizacijske karakteristike, kao npr. razina podrške i kontrole na poslu) i transakcijske karakteristike (npr. zadovoljstvo poslom, atribucije itd.) (Chang, 2009). Međutim, 
dodatni razlog navedenog može biti što je emocionalni napor ispitivan u kontekstu rada s učenicima, a zanemareni su drugi važni izvori emocija u radu nastavnika (roditelji, kolege, ravnatelj, stručna služba, sustav), pa je moguće da bi se s općenitijom mjerom emocionalnog napora koja bi obuhvaćala sve interakcije na radnom mjestu nastavnika, povećao i udio objašnjene varijance izgaranja.

U interpretaciji dobivenih rezultata treba uzeti u obzir i ostala ograničenja. Prvo, treba uzeti u obzir da je odaziv nastavnika u ovom istraživanju, u odnosu na ciljanu populaciju nastavnika kojima je poslan upitnik u prvom valu istraživanja, iznosio tek $35 \%$. S obzirom na to može se postaviti pitanje koliko se razlikuju nastavnici koji su dobrovoljno sudjelovali u ovom istraživanju od ukupne populacije nastavnika. Sudeći po deskriptivnim pokazateljima, nastavnici u ovom uzorku imaju relativno niske razine izgaranja te češće koriste dubinsku od površinskih strategija emocionalnog napora, što može biti uvjetovano prigodnošću uzorka. Nadalje, dobiveno može biti i rezultat korištene metode. Naime, u istraživanju su korištene isključivo mjere samoprocjene, što osim problema zajedničke varijance uvjetovane metodom nosi i rizik od postojanja iskrivljenih i socijalno poželjnih odgovora. Sudionicima je zajamčena anonimnost, no ipak, navedeno nije garancija nedavanja socijalno poželjnih odgovora, a s obzirom na očekivanja radne uloge, zasigurno nije socijalno poželjno iznositi tvrdnje o neautentičnosti (prikrivanju i glumljenju osjećaja) te iscrpljenosti i otuđenosti od učenika. Konačno, korelacijska priroda nacrta ne dopušta uzročno-posljedično zaključivanje. Rezultati su u skladu s teorijskim postavkama prema kojima strategije emocionalnog napora doprinose iscrpljenosti i otuđenosti, ali smjer odnosa može biti i takav da nastavnici koji su već iscrpljeni i otuđeni više koriste površinsku, a manje dubinsku strategiju emocionalnog napora. Stoga je odnos strategija emocionalnog napora i izgaranja potrebno provjeriti daljnjim istraživanjima u koja bi bilo korisno uključiti i dodatne varijable, primjerice zadovoljstvo poslom (Yin, 2015).

\section{LITERATURA}

Ashforth, B. E. i Humphrey, R. H. (1993). Emotional labor in service roles: The influence of identity. Academy of Management Review, 18, 88-115.

Bakker, A. B., Demerouti, E. i Verbeke, W. (2004). Using the job demands-resources model to predict burnout and performance. Human Resource Management, 43, 83-104.

Brotheridge, C. M. (2006). A review of emotional labour and its nomological network: practical and research implications. Ergonomia, 28, 295-309.

Brotheridge, C. M. i Grandey, A. A. (2002). Emotional labor and burnout: Comparing two perspectives of "people work". Journal of Vocational Behaviour, 60, 17-39.

Brotheridge, C. M. i Lee, R. T. (2002). Testing a conservation of resources model of the dynamics of emotional labor. Journal of Occupational Health Psychology, 7, 57-67.

Brotheridge, C. M. i Lee, R. T. (2003). Development and validation of the Emotional labour scale. Journal of Occupational and Organizational Psychology, 76(3), 365-379. 
Brown, T. A. (2006). Confirmatory factor analysis for applied research. New York: The Guilford Press.

Burić, I. i Slišković, A. (2018). Oldenburški upitnik izgaranja U: A. Slišković, I. Burić, V. Ćubela Adorić, M. Nikolić, I. Tucak Junaković (ur.), Zbirka psihologijskih skala i upitnika, svezak 9, str. 13-20. Sveučilište u Zadru.

Burić, I., Slišković, A. i Macuka, I. (2017). A mixed-method approach to the assessment of teachers' emotions: Development and validation of the Teacher Emotion Questionnaire. Educational Psychology, objavljeno online, doi: 10.1080/01443410.2017.1382682, $1-25$

Chan, D. W. (2006). Emotional intelligence and components of burnout among Chinese secondary school teachers in Hong Kong. Teaching and Teacher Education, 22, 1042-1054.

Chang, M. L. (2009). An appraisal perspective of teacher burnout: Examining the emotional work of teachers. Educational Psychology Review, 21, 193-218.

Chau, S. L., Dahling, J. J., Levy, P. E. i Diefendorff, J. M. (2009). A predictive study of emotional labor and turnover. Journal of Organizational Behaviour, 30, 1151-1163.

Cheung, F., Tang, C. S. K. i Tang, S. (2011). Psychological capital as a moderator between emotional labor, burnout, and job satisfaction among school teachers in China. International Journal of Stress Management, 18, 348-371.

Çukur, C. S. (2009). The development of the Teacher Emotional Labor Scale (TELS): Validity and reliability. Educational Sciences: Theory and Practice, 9, 559-574.

Demerouti, E. i Bakker, A. B. (2008). The Oldenburg Burnout Inventory: A good alternative to measure burnout and engagement. U. J. Halbesleben (ur.), Stress and burnout in health care (str. 65-78). New York: NovaSciences, Hauppauge.

Demerouti, E., Bakker, A. B., Vardakou, I. i Kantas, A. (2003). The convergent validity of two burnout instruments: A multitrait-multimethod analysis. European Journal of Psychological Assessment, 18, 296-307.

Demerouti, E., Mostert, K. i Bakker, A. B. (2010). Burnout and work engagement: A thorough investigation of the independency of both constructs. Journal of Occupational Health Psychology, 15, 209-222.

Ghanizadeh, A. i Royaei, N. (2015). Emotional facet of language teaching: Emotion regulation and emotional labor strategies as predictors of teacher burnout. International Journal of Pedagogies and Learning, 10, 139-150.

Grandey, A. A. (2000). Emotion regulation in the workplace: A new way to conceptualize emotional labor. Journal of Occupational Health Psychology, 5, 95-110.

Grandey, A. A. (2003). When "The show must go on": Surface acting and deep acting as determinants of emotional exhaustion and Peer-rated service delivery. Academy of Management Journal, 46, 86-96.

Hu, L. i Bentler, P. M. (1999). Cutoff criteria for fit indexes in covariance structure analysis: Conventional criteria versus new alternatives. Structural Equation Modeling, 6(1), $1-55$.

Kadum, V., Vidović, S. i Vranković, K. (2007). Gledišta učitelja o svojem statusu, motivaciji i Hrvatskom nacionalnom obrazovnom standardu. Napredak, 148(2), 192-209.

Kinman, G., Wray, S. i Strange, C. (2011). Emotional labour, burnout and job satisfaction in UK teachers: the role of workplace social support. Educational Psychology, 31, 843-856. 
Kyriacou, C. (2001). Teacher stress: directions for future research. Educational Review, 53, 27-35.

Lee, R. T. i Brotheridge, C. M. (2011). Words from the heart speak to the heart: A study of deep acting, faking and hiding among child care workers. Career Development International, 16, 401-420.

Maslach, C. i Jackson, S. E. (1981). The measurement of experienced burnout. Journal of Occupational Behaviour, 2, 99-113.

Montgomery, C. i Rupp, A.A. (2005). A meta-analysis for exploring the diverse causes and effects of stress in teachers. Canadian Journal of Education, 28, 458-486.

Näring, G., Briët, M. i Brouwers, A. (2006). Beyond demand-control: Emotional labour and symptoms of burnout in teachers. Work \& Stress: An International Journal of Work, Health \& Organisations, 20, 303-315.

Noor, N. M. i Zainuddin, M. (2011). Emotional labor and burnout among female teachers: Work-family conflict as mediator. Asian Journal of Social Psychology, 14, 283-293.

Philipp, A. i Schüpbach, H. (2010). Longitudinal effects of emotional labour on emotional exhaustion and dedication of teachers. Journal of Occupational Health Psychology, 15, 494-504.

Radeka, I. i Sorić, I. (2006). Zadovoljstvo poslom i profesionalni status nastavnika. Napredak, 147(2), 161-177.

Rijavec, M., Pečjak, S., Jurčec, L. i Gradišek, P. (2016). Money and Career or Calling? Intrinsic vs. Extrinsic Work Orientations and Job Satisfaction of Croatian and Slovenian Teachers. Croatian Journal of Education, 18(1), 201-223.

Schmidt, K. H. i Diestel, S. (2014). Are emotional labour strategies by nurses associated with psychological costs? A cross-sectional survey. International Journal of Nursing Studies, 51, 1450-1461.

Slišković, A. (2016). Stres u radu: Pregled područja s praktičnim implikacijama za ravnatelje odgojno-obrazovnih institucija. U: D. Vican, I. Sorić i I. Radeka (ur.) Upravljanje odgojno-obrazovnom ustanovom: kompetencijski profil ravnatelja. Sveučilište u Zadru.

Slišković, A., Burić, I. i Macuka, I. (2016). The voice of Croatian elementary school teachers: qualitative analysis of the teachers' perspective on their profession. Teachers and Teaching: Theory and Practice, 23(5), 518-531.

Slišković, A. i Maslić Seršić, D. (2011). Work stress among university teachers: Gender and position differences. Archive for Industrial Hygiene and Toxicology, 62(4), 299-307.

Sutton, R. E. i Wheatley, K. F. (2003). Teacher's emotions and teaching: A review of the literature and directions for future research. Educational Psychology Review, 15, 327-358.

Tsang, K. K. (2011). Emotional labor of teaching. Educational Research, 2, 1312-1316.

Vizek Vidović, V. (2005). Cjeloživotno obrazovanje učitelja i nastavnika: Višestruke perspektive. Zagreb: Institut za društvena istraživanja.

Vidić, T. (2009). Zadovoljstvo poslom učitelja u osnovnoj školi. Napredak, 150(1), 7-20.

Winograd, K. (2003). The functions of teacher emotions: The good, the bad, and the ugly. Teachers College Record, 105, 1641-1673.

Yin, H. (2015). The effect of teachers' emotional labour on teaching satisfaction: moderation of emotional intelligence. Teachers and Teaching: theory and practice, 21, 789-810. 
Yin, H. i Lee, J. C.-K. (2012). Be passionate, but be rational as well: Emotional rules for Chinese teachers' work. Teaching and Teacher Education, 28(1), 56-65.

Yin, H. B., Lee, J. C. K., Zhang, Z. H. i Jin, Y. L. (2013). Exploring the relationship among teachers' emotional intelligence, emotional labor strategies and teaching satisfaction. Teaching and Teacher Education, 35, 137-145.

\title{
THE ROLE OF EMOTIONAL LABOUR STRATEGIES IN THE EXPLANATION OF TEACHERS'BURNOUT
}

\begin{abstract}
Although predictors and consequences of burnout in different occupations, including the teaching profession, represent a relatively frequent research topic, the role of emotional labour strategies in the explanation of core dimensions of burnout is less tested, especially in Croatian teachers. Therefore, the aim of this study was to test the role of emotional labour strategies (deep acting, and two types of surface acting; hiding feelings and faking emotions) in the explanation of exhaustion and disengagement. The sample consisted of 1955 teachers in total, whereby 581 of them were class-teachers in elementary school, 716 subject-teachers in elementary schools, and 536 were teachers in secondary school. The female teachers were more represented in the sample (1648 female teachers and 307 male teachers). The age of teachers ranged from 23 to 68 years $(M=42,38, S D=10,12)$. The results showed a significant, although relatively small, contribution of emotional labour strategies in the explanation of burnout among teachers. Teachers who use surface acting strategies (hiding feelings and faking emotions) have higher levels of exhaustion and disengagement. In contrast to this, teachers who use deep acting have lower levels of the two burnout dimensions.
\end{abstract}

Key words: emotional labour strategies, burnout, teachers 
